\title{
Design and fabrication of wave generator using an oscillating wedge
}

\author{
Lu Thi Yen Vu ${ }^{1}$, Ha Phuong ${ }^{2}$, Ho Xuan Thinh ${ }^{3}$, Dao Thanh Liem², Truong Quoc Thanh ${ }^{2, *}$, Tran Doan Son ${ }^{2, *}$
}

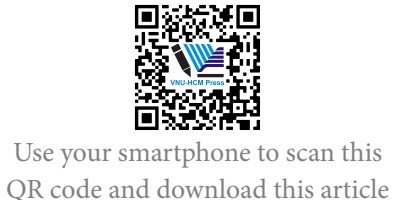

${ }^{1}$ Ly Tu Trong College of Ho Chi Minh City, Vietnam

${ }^{2}$ Faculty of Mechanical Engineering, University of Technology, VNU-HCM, Vietnam

${ }^{3}$ Vietnamese - German University, Vietnam

Correspondence

Truong Quoc Thanh, Faculty of Mechanical Engineering, University of Technology, VNU-HCM, Vietnam

Email: tqthanh@hcmut.edu.vn

Correspondence

Tran Doan Son, Faculty of Mechanical Engineering, University of Technology, VNU-HCM, Vietnam

Email: tdson@hcmut.edu.vn

History

- Received: 10-10-2018

- Accepted: 28-12-2018

- Published: 31-12-2019

DOI : 10.32508/stdjet.v3iSI1.727

Check for updates

\begin{abstract}
This paper describes the design and fabrication of a wave flume. The wave maker is made by a triangle wedge. Wave flume size is $0.75(\mathrm{~m})$ in width, $1.3(\mathrm{~m})$ in height and $11(\mathrm{~m})$ in length. The characteristic of a generation wave is also conducted in this research. An experimental results of the crated wave is considered by two operation parameters (Eccentricity and Rotation speed). Wave flume is equipped with a triangle wedge which located at one end of the wave flume, and it can be move along the rail of the wave flume. The passive wave absorber which is made of honey comb which is located at the other end of the wave flume for absorbing energy waves generated from the wave maker. The wedge is controlled by a desktop computer via Matlab Simulink. The wedge is controlled move up and down at a prescribed speed, hence the wave amplitude leading to change the height and frequency. At the middle flume is equipped micro laser distance sensor which provides data-logging capability. A Micro laser distance sensor can collect wave height and wave period through a small ball which is motioned in the tube. The ball is very light to avoid inertia. The wave maker is equipped by a cable sensor to measuring the eccentricity. Wave flume can generate the largest wave energy such as: wave-amplitude is $0.2(\mathrm{~m})$, wave-length is $1.5(\mathrm{~m})$ and frequency is $1(\mathrm{~Hz})$. The waves generated by a oscillating wedge have been measured, analyzed to consider the generated wave energy.
\end{abstract}

Key words: Wave Energy, Wave Flume, Wave Generation, Wave Maker

\section{INTRODUCTION}

Ocean wave energy is the natural resource to be exploited as a renewable source of energy, while also coinciding with the aim of reducing our reliance on fossil fuel sources. The concept of harnessing ocean wave energy is by no means a new idea. Modern research into harnessing energy from waves was stimulated by the emerging oil crisis of the $1970 \mathrm{~s}^{1}$. With global attention now being drawn to climate change and the rising level of $\mathrm{CO}_{2}$, the focus on generating electricity from renewable sources is once again an important area of research. At present, many countries in the world use wave energy as a source of clean and renewable energy ${ }^{2,3}$ (Figure 1).

Therefore, experimental wave flumes are very useful to test the performance of wave energy conversions. The wave generation is made through a wave-maker animated with a prescribed motion with specified amplitude and frequency ${ }^{4}$. Three main classes of mechanical type wavemakers are utilized in laboratory: The first is the movable wall type generators ${ }^{5}$, including piston and paddle-type wavemaker, which generates waves by a simple oscillatory motion in the direction of wave propagation (Figure 2). The movable wall type generators are used where the water is shallow compared to the wavelength of the waves. Here the orbital particle motion is compressed into an ellipse and there is significant horizontal motion on floor of the tank. This type of paddle is used to generate waves for modelling coastal structures, harbours and shore mounted wave energy devices.

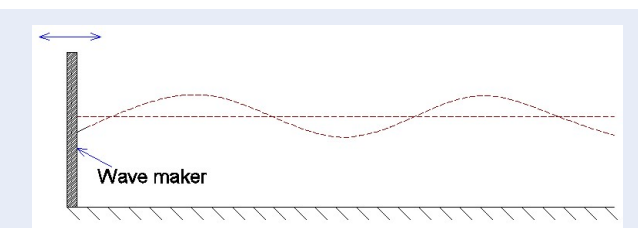

Figure 2: The movable wall type generators.

The second is the plunger-type wavemakers ${ }^{5}$, which generates waves by oscillating vertically in the surface of water (Figure 3). The plunger-type wavemakers are commonly used in wave flumes because they can be fabricated as fairly long wave machines and they easily relocated within the flumes. The machine is very compact, furthermore, as the shape is wedge, the flume can be designed to work with water behind the wave maker with almost no generation of back waves ${ }^{4}$. 


\section{Copyright}

( $)$ VNU-HCM Press. This is an openaccess article distributed under the terms of the Creative Commons

Attribution 4.0 International license.



VNU-HCM Press

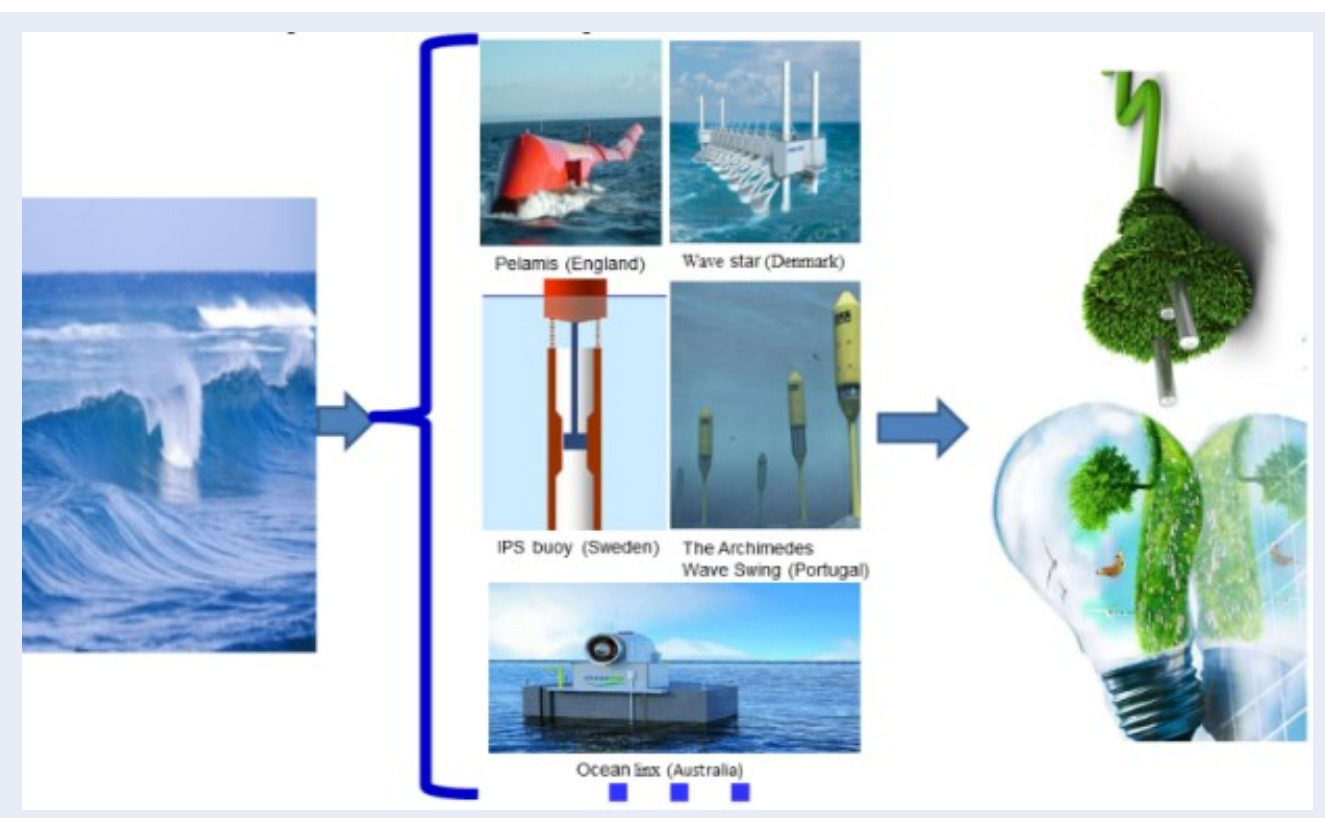

Figure 1: Some of typical wave energy converter on over the world.

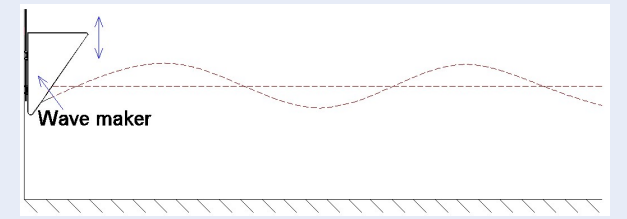

Figure 3: The plunger-type wave makers.

The third is the flap-type wave-maker, which is located at one end of the tank ${ }^{6}$, and hinged on a sill (Figure 4), waves are generated by oscillation of the flap about the sill, flap-type wave-maker is used to produce deep water waves where the orbital particle motion decays with depth and there is negligible motion at the bottom.

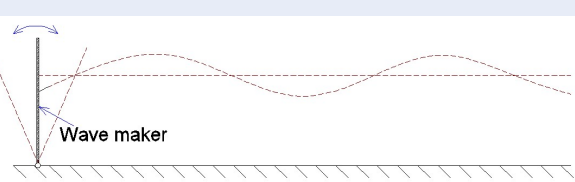

Figure 4: Flap-type wave-maker.

This paper describes the design and fabrication of a wave flume with the plunger-type wavemakers and associated equipment, the waves generated by a sinusoidal oscillating wedge have been measured and analyzed.

\section{DESIGN AND FABRICATION}

\section{Wave Flume}

Experiments were performed in a concrete wave flume which is 0.75 -meter-wide, 1.3 -meter-tall and 11 meters long (Figure 5a). The water depth was maintained at 0.97 meters. The one side of the flume is made of 1-cm-thick clear mica sheets for observe the water waveform, mica sheets are supported by steel structural frames, the other side is the concrete wall (Figure 5b).

\section{Wave Gauges and Data Acquisition}

A Micro Laser Distance Sensor (HG-C1400Panasonic) is used for measuring the wave height. This sensor is located at the middle of the tank and it isn't contacted with water so not affect parameters of the wave. This is also the advantage of this design. Additionally, an Eccentricity Sensor is used to measure the wedge position (Figure 6a).

\section{Wave-Maker}

Waves were generated using a wedge shaped plunger device, the 35 degree wedge has been chosen for the wave-maker because 35 degree wedge is so good for wave-maker performance in ${ }^{7}$. It is set at one end of the tank (Figure 6b) and is made of 1-mm-thick Inox sheets, it can generate regular waves. The wedge has a $0.418 \mathrm{~m}$ base and $0.566 \mathrm{~m}$ height, with a mean submergence height of $0.375 \mathrm{~m}$ (Figure 7). The wedge is 


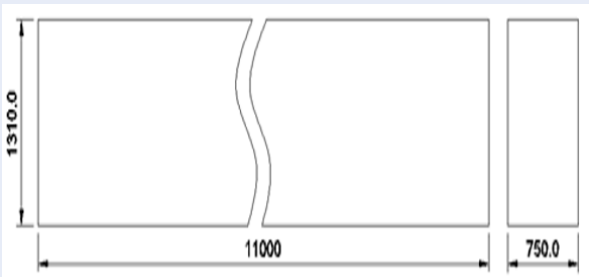

(A)

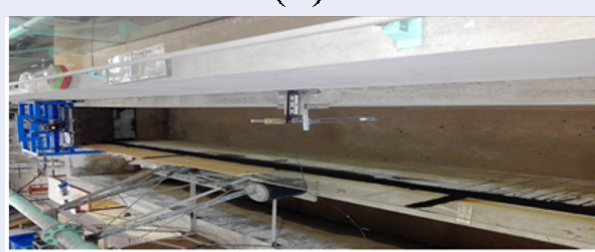

(B)

Figure 5: (a) Scheme of the wave flume; (b) Panoramic view of the wave flume.

operated by $1 \mathrm{~kW}$ electric linear servo motor, which is controlled by computer. The installed wave-maker is capable of generating regular waves from $0.7 \mathrm{~s}$ up to $3 \mathrm{~s}$ period and $0.7 \mathrm{~m}$ up to $14 \mathrm{~m}$ wave length (case by case). The servo motor is programmed to provide sinusoidal input motion to the Wave-Maker ${ }^{8}$.

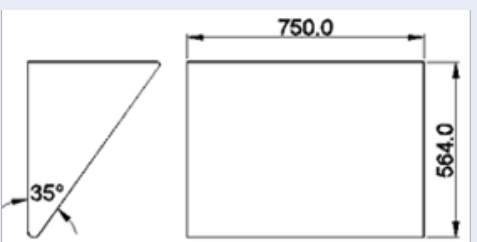

(A)

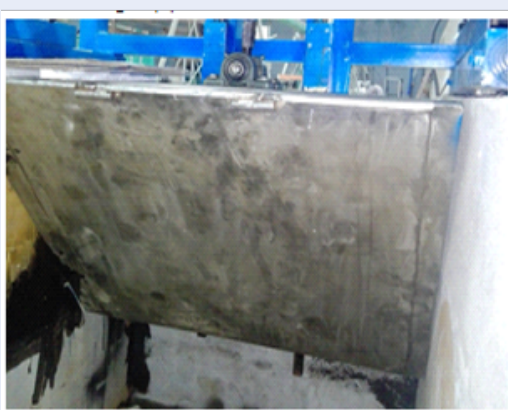

(B)

Figure 7: (a) Scheme of the Wave-Marker; (b) Panoramic view of the Wave-Marker.

\section{Wave Absorber}

Wave absorber is the most important part in a wave flume. A great variety of designs and materials have been used throughout the world for the construction of wave absorbers. Wave absorbers could be classified into two main categories: active and passive absorbers. Active absorbers owning to its high cost is still very limited, except in a few cases where the wave board itself is programmed to absorb the reflected wave. In this design uses passive absorbers, the wave absorber has 1:4 slopes ${ }^{9}$. It is located at the end of the tank opposite to the wave-maker (Figure 6c). The waves generated are absorbed using a honey comb which is set at the other one end of the tank (Figure 8).

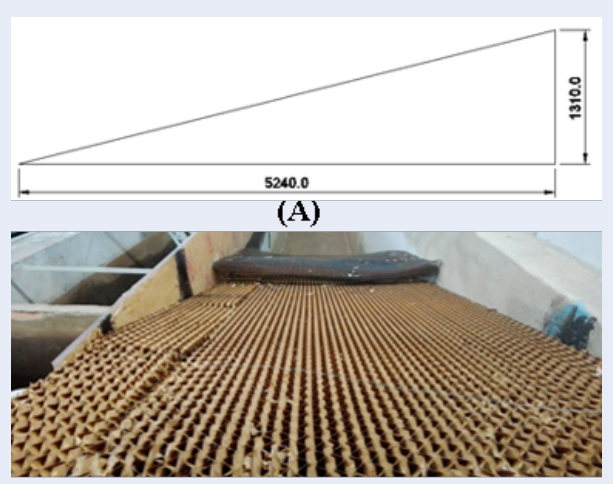

(B)

Figure 8: (a) Scheme of the Wave-Absorber; b) Panoramic view of the Wave-Absorber.

\section{THEORETICAL APPROACH}

Many models can be used to try to describe the evolution of the surface elevation in time and space. One of the most used, because of the simplicity that results of assuming linearity of the potential flow function, is the one related to the linear wave theory ${ }^{10}$.

$$
\eta(x ; t)=A \cos (\omega t-k x)
$$

The main parameters that define a wave are amplitude (A), period (T) and wavelength (L), represented in Figure 9. The amplitude corresponds to half of the wave height $(\mathrm{H})$, the vertical distance between the highest and the lowest surface elevation in a wave. The time interval between the start and the end of the wave is what is known as the period of a wave. Finally, the wavelength is the distance between two successive peaks or two consecutive troughs. Table 1 and Figure 9 summarize a commonly used wave energy nomenclature. 

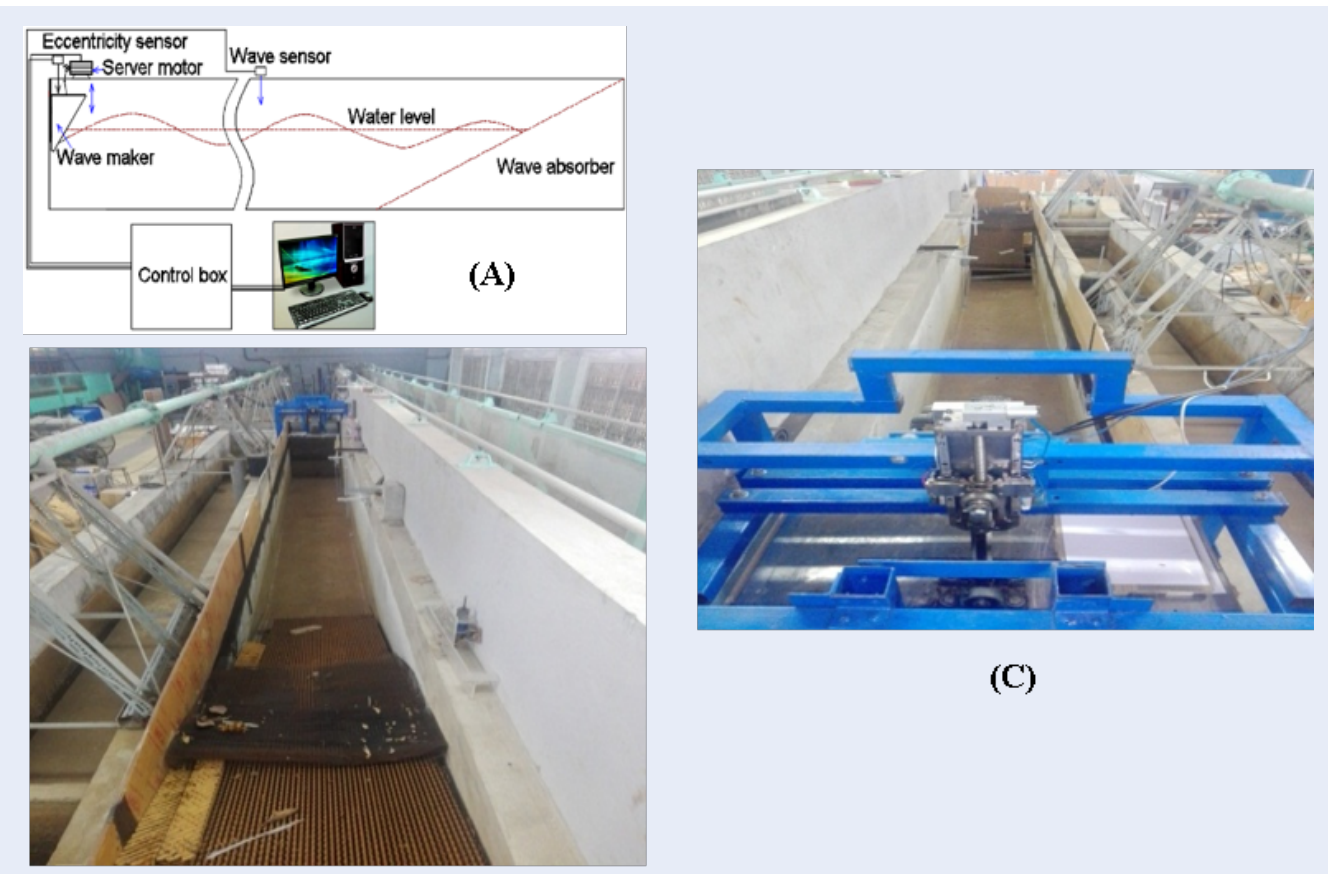

(C)

(B)

Figure 6: (a) Scheme of the wave flume used in the experimental set up; (b) Panoramic view of the wave flume (look at the end of the flume); (c) Panoramic view of the wave flume (look at the beginning of the flume).

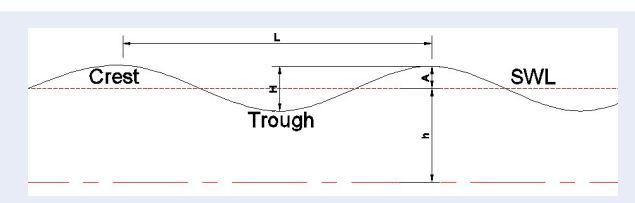

Figure 9: Sine wave pattern and associated parameters in waves.

Energy and power density: The energy density of a wave is the mean energy flux crossing a vertical plane parallel to a wave's crest. The energy per wave period is the wave's power density and can be found by dividing the energy density by the wave period.

$$
\begin{gathered}
E_{\text {density }}=\frac{\rho g H^{2}}{8}=\frac{\rho g A^{2}}{2} \\
P_{\text {density }}=\frac{E_{\text {density }}}{T}=\frac{\rho g H^{2}}{8 T}=\frac{\rho g A^{2}}{2 T}
\end{gathered}
$$

Power per meter of wave front: A wave resource is typically described in terms of power per meter of wave front (wave crest). This can be calculated by multiplying the energy density by the wave front velocity.

$$
P_{\text {wavefront }}=C \cdot E_{\text {density }}=\frac{L \rho g H^{2}}{8 T}
$$

$$
E_{\text {wavefront }}=P_{\text {wavefront }} \cdot T
$$

\section{RESEACH METHOD, RESULT AND DISCUSSION}

The research method is used in this paper is experiment method. We experiment with many difference parameters of system to consider the generated wave energy.

The list of experimental tests are presented in Table 2. These tests were chosen to show the wave height range of $12 \mathrm{~mm}$ to $200 \mathrm{~mm}$, wavelength range of $0.7 \mathrm{~m}$ to $14 \mathrm{~m}$. The water depth was maintained at 0.97 meters. From Table 2, we draw Figure 10. According to Figure 10, we find that the wave's power density is related to eccentricity, which can be predicted linearly. May be, the experimental system is not good. So, there are many places that do not follow the linear relationship. Table 3, we draw Figure 11. According to Figure 11, we see that the wave's power density is related to the RPM, which can predict as a second order. When $\mathrm{RPM}$ is greater than $68 \mathrm{r} / \mathrm{m}$; the waves are interrupted. Table 4, we drawFigure 12. According to Figure 12, when increasing eccentricity $(\mathrm{e}=100 \mathrm{~mm})$; the wave's 


\begin{tabular}{lllll}
\hline \multicolumn{2}{l}{ Table 2: List of experimental tests $\mathbf{( R P M}=\mathbf{5 0} \mathbf{~} \mathbf{/ m})$} & & \\
\hline $\mathrm{e}(\mathrm{mm})$ & $\mathrm{T}(\mathrm{s})$ & $\mathrm{H}(\mathrm{mm})$ & $\mathrm{L}(\mathrm{m})$ & Pdensity $\left(\mathrm{w} / \mathrm{m}^{2}\right)$ \\
80 & 0.895 & 99.656 & 1.250 & 13.606 \\
85 & 0.895 & 102.661 & 1.251 & 14.434 \\
$\ldots$ & $\ldots$ & $\ldots$ & $\ldots$ & $\ldots$ \\
145 & 0.896 & 167.101 & 1.254 & 38.197 \\
150 & 0.896 & 180.486 & 1.254 & 44.562 \\
155 & 0.894 & 180.023 & 1.249 & 44.430 \\
\hline
\end{tabular}

\begin{tabular}{|c|c|c|}
\hline Name & Description & Units/Value \\
\hline$\eta$ & The water surface & $\mathrm{m}$ \\
\hline $\mathrm{t}$ & Time & \\
\hline $\mathrm{x}$ & Space & $\mathrm{m}$ \\
\hline $\mathrm{w}$ & Wave frequency & $\mathrm{rad} / \mathrm{s}$ \\
\hline $\mathrm{k}$ & The wavenumber & $\mathrm{rad} / \mathrm{m}$ \\
\hline $\mathrm{E}_{\text {density }}$ & Wave energy density & $\mathrm{J} / \mathrm{m}^{2}$ \\
\hline $\mathrm{E}_{\text {wavefront }}$ & $\begin{array}{l}\text { Energy per meter wave } \\
\text { front }\end{array}$ & $\mathrm{J} / \mathrm{m}$ \\
\hline $\mathrm{P}_{\text {density }}$ & Wave power density & $\mathrm{W} / \mathrm{m}^{2}$ \\
\hline $\mathrm{P}_{\text {wavefront }}$ & Power per meter wave front & $\mathrm{W} / \mathrm{m}$ \\
\hline SWL & Mean water level (surface) & \\
\hline $\mathrm{h}$ & Depth below SWL & $\mathrm{m}$ \\
\hline $\mathrm{L}$ & Wavelength & $\mathrm{m}$ \\
\hline$\rho$ & Sea water density & $\begin{array}{l}1000 \\
\mathrm{~kg} / \mathrm{m}^{3}\end{array}$ \\
\hline $\mathrm{g}$ & Gravitational constant & $9.81 \mathrm{~m} / \mathrm{s}^{2}$ \\
\hline A & Wave amplitude & $\mathrm{m}$ \\
\hline $\mathrm{H}$ & Wave height & $\mathrm{m}$ \\
\hline $\mathrm{T}$ & Wave period & \\
\hline $\mathrm{C}$ & $\begin{array}{l}\text { Celerity (wave front veloc- } \\
\text { ity) }\end{array}$ & $\mathrm{m} / \mathrm{s}$ \\
\hline RPM & Round per minute & $\mathrm{r} / \mathrm{m}$ \\
\hline e & Eccentricity & $\mathrm{mm}$ \\
\hline
\end{tabular}

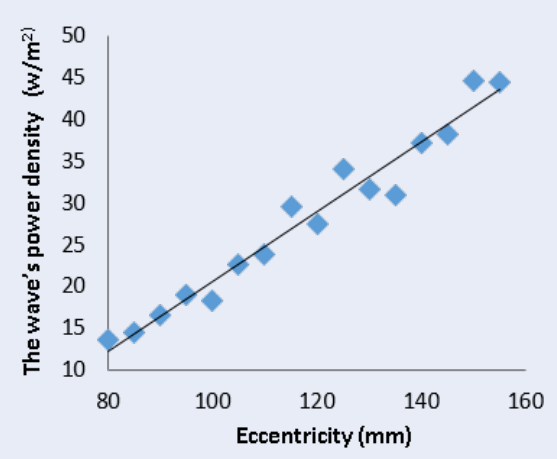

Figure 10: Eccentricity efficiency.

Table 3: List of experimental tests $(\mathrm{e}=\mathbf{8 0} \mathrm{mm})$

\begin{tabular}{lllll}
\hline RPM & T (s) & H $(\mathrm{mm})$ & $\mathrm{L}(\mathrm{m})$ & $\begin{array}{l}\text { Pdensity } \\
\left(\mathrm{w} / \mathrm{m}^{2}\right)\end{array}$ \\
20 & 2.221 & 35.669 & 7.704 & 0.702 \\
22 & 2.069 & 88.884 & 6.686 & 4.681 \\
$\ldots$ & $\ldots$ & $\ldots$ & $\ldots$ & $\ldots$ \\
64 & 0.697 & 137.94 & 0.758 & 33.473 \\
66 & 0.681 & 141.10 & 0.725 & 35.827 \\
68 & 0.659 & 144.77 & 0.678 & 38.997 \\
\hline
\end{tabular}

Table 4: List of experimental tests $(e=100 \mathrm{~mm})$

\begin{tabular}{lllll}
\hline RPM & T $(\mathrm{s})$ & $\mathrm{H}(\mathrm{mm})$ & $\mathrm{L}(\mathrm{m})$ & $\begin{array}{l}\text { Pdensity } \\
\left(\mathrm{w} / \mathrm{m}^{2}\right)\end{array}$ \\
20 & 2.217 & 28.202 & 7.673 & 0.439 \\
22 & 2.069 & 74.062 & 6.684 & 3.250 \\
$\ldots$ & $\ldots$ & $\ldots$ & $\ldots$ & $\ldots$ \\
62 & 0.723 & 161.510 & 0.816 & 44.224 \\
64 & 0.698 & 165.402 & 0.761 & 48.034 \\
66 & 0.682 & 170.754 & 0.726 & 52.409 \\
\hline
\end{tabular}




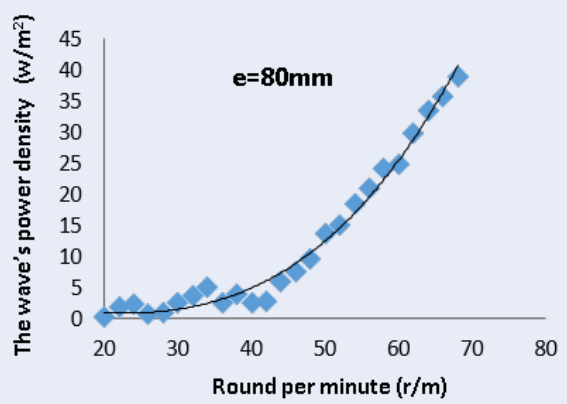

Figure 11: RPM efficiency and Eccentricity efficiency.

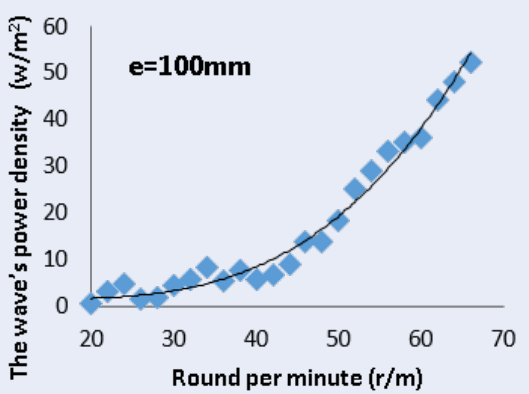

Figure 12: RPM efficiency and Eccentricity efficiency.

power density increases. When RPM is greater than $66 \mathrm{r} / \mathrm{m}$; the waves are interrupted.

Table 5: List of experimental tests $(e=120 \mathrm{~mm})$

\begin{tabular}{lllll}
\hline RPM & T (s) & H $(\mathrm{mm})$ & $\mathrm{L}(\mathrm{m})$ & $\begin{array}{l}\text { Pdensity } \\
\left(\mathrm{w} / \mathrm{m}^{2}\right)\end{array}$ \\
20 & 2.221 & 35.669 & 7.704 & 0.702 \\
22 & 2.069 & 88.884 & 6.686 & 4.681 \\
$\ldots$ & $\ldots$ & $\ldots$ & $\ldots$ & $\ldots$ \\
56 & 0.8 & 167.965 & 1.001 & 43.198 \\
58 & 0.773 & 164.519 & 0.933 & 42.914 \\
60 & 0.749 & 165.567 & 0.877 & 44.828 \\
\hline
\end{tabular}

Table 5, we draw Figure 13. In Figure 13, when e= 120 , the graph has more fluctuation, due to the influence of reflectivity. When RPM is greater than $60 \mathrm{r} / \mathrm{m}$; the waves are interrupted

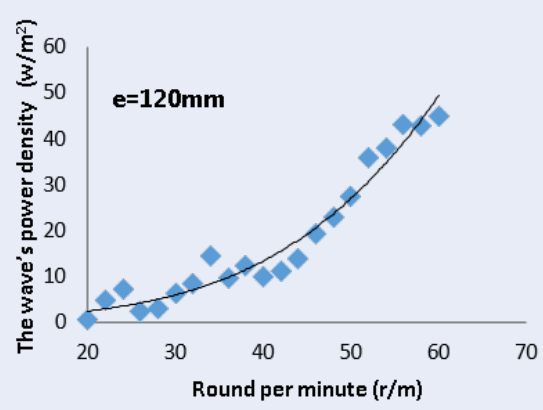

Figure 13: RPM efficiency and Eccentricity efficiency.

\begin{tabular}{ccccc}
\multicolumn{5}{c}{ Table 6: List of experimental tests (e=140mm) } \\
\hline RPM & $\mathrm{T}(\mathrm{s})$ & $\mathrm{H}(\mathrm{mm})$ & $\mathrm{L}(\mathrm{m})$ & $\begin{array}{l}\text { Pdensity } \\
\left(\mathrm{w} / \mathrm{m}^{2}\right)\end{array}$ \\
20 & 2.215 & 40.556 & 7.660 & 0.910 \\
22 & 2.067 & 102.937 & 6.675 & 6.283 \\
$\ldots$ & $\ldots$ & $\ldots$ & $\ldots$ & $\ldots$ \\
54 & 0.827 & 178.080 & 1.068 & 46.999 \\
56 & 0.798 & 181.131 & 0.995 & 50.377 \\
58 & 0.767 & 185.804 & 0.919 & 55.155 \\
\hline
\end{tabular}

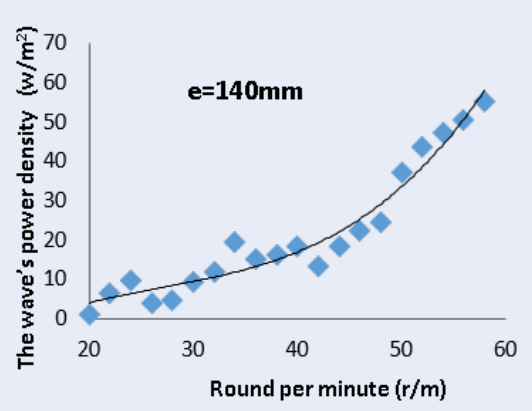

Figure 14: RPM efficiency and Eccentricity efficiency.

Table 6, we draw Figure 14. In Figure 14, when increasing eccentricity longer; fluctuation as much, due to the influence of reflectivity so much. When RPM is greater than $58 \mathrm{r} / \mathrm{m}$; the waves are interrupted.

Figure 15 illustrate how RPM and eccentricity affect the wave's power density. The wave's power density is significantly affected by RPM and Eccentricity. 




Figure 15: The influence of RPM and Eccentricity.

\section{CONCLUSION}

In this paper, the system wave flume is described and fabrication for a study and built with a limited budget, however, it is well-suited to educational and research studies about wave energy. The performance of the physical wave maker and wave absorber was evaluated over a range of frequencies and eccentricity. The results also show that the wave's power density significantly affected by RPM and Eccentricity. The affected of reflectivity is so much, further work, we will improve the performance of the wave absorber in the wave flume to minimize the reflected waves.

\section{CONFLICT OF INTEREST}

The authors hereby warrant that this paper is no conflict of interest with any publication.

\section{AUTHOR'S CONTRIBUTION}

Ms. Lu Thi Yen Vu played a role as an executer, analyzed experimental data and wrote the paper.

MSc. Ha Phuong fabricated mechanical equipment and managed all experimental process.

Dr. Dao Thanh Liem and Dr. Ho Xuan Thinh suggested the mechanical design.

Dr. Truong Quoc Thanh contributed for writing paper.
Ass. Prof Tran Doan Son played a role as a corresponding author.

\section{ACKNOWLEDGEMENTS}

This research is funded by Ho Chi Minh City University of Technology-VNU-HCM under grant number T-KTXD-2019-40.

\section{REFERENCES}

1. Salter SH. Wave power. Nature. 1974;249:720-724. Available from: https://doi.org/10.1038/249720a0.

2. d O Antonio F. Wave energy utilization: A review of the technologies. Renewable and sustainable energy reviews. 2010;14:899-918. Available from: https://doi.org/10.1016/j. rser.2009.11.003.

3. Enferad E, Nazarpour D. Ocean's Renewable Power and Review of Technologies. Case Study Waves: INTECH Open Access Publisher. 2013;Available from: https://doi.org/10.5772/53806.

4. GUILLOUZOUIC B. D2. 12 Collation of Wave Simulation Methods. Energy Research Centre of the Netherlands (ECN), Institute for Technological Research (IPT), Plymouth University, Queen's University Belfast, The French Research Institute for Exploitation of the Sea (IFREMER), University College Cork, and University of Edinburgh. 2014;p. 85.

5. Wu YC. Plunger-type wavemaker theory. Journal of Hydraulic Research. 1988;26:483-491. Available from: https://doi.org/ $10.1080 / 00221688809499206$.

6. Lal A, Elangovan M. CFD simulation and validation of flap type wave-maker. World Academy of Science, Engineering and Technology. 2008;46:76-82.

7. Mikkola T. Simulation of plunger-type wave makers. Journal of Structural Mechanics. 2007;40:19-39. 
8. Gadelho J, Lavrov A, Soares CG, Urbina R, Cameron M, Thiagarajan K. CFD modelling of the waves generated by a wedgeshaped wave maker. 2015;Available from: https://doi.org/10. 1201/b17494-133.
9. Khalilabadi M, Bidokhti A. Design and construction of an optimum wave flume. 2012;

10. Holthuijsen LH. Waves in oceanic and coastal waters: Cambridge university press. 2010;. 


\section{Thiết kế và chế tạo thiết bị tạo sóng sử dụng nêm dao động}

\section{Lư Thị Yến Vũ ${ }^{1}$, Hà Phương ${ }^{2}$, Hồ Xuân Thịnh ${ }^{3}$, Đào Thanh Liêm² ${ }^{2}$, Trương Quốc Thanh ${ }^{2, *}$, Trần Doãn Sơn ${ }^{2}$}

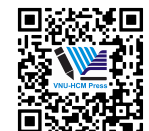

Use your smartphone to scan this QR code and download this article

\section{TÓM TẮT}

Nội dung chính của bài báo này trình bày về thiết kế và chế tao môt thiết bi tao sóng dang nêm cùng với các thiết bị phụ trợ. Kênh tạo sóng được xây dựng bằng bể tông với chiêu rộng 0.75 mét, 0.3 mét chiều cao, và chiều dài là 11 mét. Một bên thành của kênh tạo sóng được làm bằng bê tông, bên thành còn lại được làm bằng tấm mica trong suốt để quan sát biên dạng sóng. Kênh tạo sóng được trang bị hình nềm tam giác được đặt ở cuối kênh, hình nêm này có thể di chuyển dọc theo thành kênh. Bộ hấp thụ sóng thụ động đ̛ược làm bằng các tấm tổ ong nằm ở phía đầu đối diện để hấp thu năng lượng sóng nhằm ngăn sóng phản hồi. Nêm có thể di chuyển lên xuống và được điều khiển bởi một máy tính thông qua phân mêm mathlab để tạo ra được biên độ dao động và tần số mong muốn nhằm tạo ra các thông số sóng khác nhau. Tín hiêu thông số sóng được thu thập thông qua một quả banh nhỏ, rất nhẹ để tránh sự ảnh hưởng của lực quán tính, trái banh này được di chuyển trong môt ống nhưa được lắp trên mắt nước. Taii hình nềm tao sóng được lắp môt cảm biến đo đô lệch tâm để đo vị trí của hình nêm và phản hồi vể máy tính điêu khiển. Thiết bị tạo sóng có thể tạo ra sóng với biên độ sóng lớn nhất khoảng 0,2 (mét), chu kỳ khoảng 1 (giây), và bước sóng khoảng 1,5 (mét). Sóng tạo ra bởi nêm dao động đã được đo, và phân tích để xem xét năng lượng sóng.

Từ khoá: Năng lượng sóng, Mương nước tạo sóng, Tạo sóng, Máy tạo sóng
${ }^{1}$ Trường Cao Đẳng Lý Tự Trọng Tp.Hồ Chí Minh, Việt Nam

${ }^{2}$ Khoa Cơ Khí, Trường Đại học Bách khoa, ĐHQG-HCM, Việt Nam

${ }^{3}$ Trường Đại học Việt Đức, Việt Nam

Liên hệ

Trương Quốc Thanh, Khoa Cơ Khí, Trường Đại học Bách khoa, ĐHQG-HCM, Việt Nam

Email: tqthanh@hcmut.edu.vn

Lịch sử

- Ngày nhận: 10-10-2018

- Ngày chấp nhận: 28-12-2018

- Ngày đăng: 31-12-2019

DOI : 10.32508/stdjet.v3iSI1.727

\section{Check for updates}

\section{Bản quyền}

๑ Đ ĐHQG Tp.HCM. Đây là bài báo công bố mở được phát hành theo các điều khoản của the Creative Commons Attribution 4.0 International license.

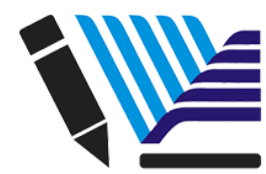

VNU-HCM Press
Trích dẫn bài báo này: Vũ $L T Y$, Phương $H$, Thịnh $H X$, Liêm $D T$, Thanh $T Q$, Sơn $T D$. Thiết kế và chế tạo thiết bị tạo sóng sử dụng nêm dao động. Sci. Tech. Dev. J. - Eng. Tech.; 2(SI1):SI103-SI111. 